\title{
結合誤差がモジュール構造の展開特性に与える影響*1 \\ A Study of the Influence of Module Connection on Deployment Characteristics of Modular Structures
}

\author{
石川博 規 ${ }^{2, * 3} \cdot$ 目 黑 在 ${ }^{* 4} \cdot$ 古 谷 寛*3 \\ Hironori Ishikawa, Akira Meguro and Hiroshi Furuya
}

Key Words : Deployable Structure, Modular Structure, Module Connection

\begin{abstract}
The influence of module connection appeared in the changes in the internal force during deployment motion. When the internal force arises in a deployable structure during deployment, two major resistance factors affect the deployable characteristics. One is friction in each hinge portion. Another is strain energy due to structural deformation. To evaluate the influence of module connection on deployment characteristics, we performed deployment experiments under micro gravity. The changes in deployment force were measured for given tolerance of connection points. We concluded that the major resistance factor was strain energy due to structural deformation.
\end{abstract}

1. は じめ に

現在 , 次世代衛星通信サービスの実現をめざし , 軽量で 大形の展開アンテナ $\left.{ }^{1 \sim 3}\right)$ の研究開発が行われている.これ らの展開宇宙構造物は, 軌道上における確実な展開を保証 するため，打ち上げ前に地上展開試験によって展開特性を 十分に評価される必要がある。しかしながら, 展開宇宙構 造物の形状寸法か増大するにつれて重力による影響が展開 宇宙構造物本来の展開力と比較して急激に増加し, 地上展 開試験の精度を著しく劣化させる．著者らは展開宇宙構造 物の地上展開試験による評価の難しさを表す指標とし，自 重による展開力と展開宇宙構造物の軌道上展開力とで困難 性指標值を定義し，この指標と地上展開試験による展開力 評価精度の関係を定量的に明らかにした ${ }^{4,5)}$. 光の結果，困 難性指標値が 900 を越えるような展開宇宙構造物（衛星搭 載用アンテナでは $10 \mathrm{~m}$ 級) の展開力を地上展開試験で評 価することは評価精度を著しく低下させる，ということが 明らかになった .この問題に対する解決策として，展開宇 宙構造物を分割可能な構造で設計する方法 $\left.{ }^{6}\right)$ がある. 分割 可能な展開宇宙構造物の例として, NTT で研究開発して (るモジュラーメッシュアンテナ7), 宇宙航空研究開発機構 の技術試験衛星 VIII 型 (ETS-VIII) 搭載用大形展開アン テナ8)を挙げることができる．

しかしながら，展開宇宙構造物を評価可能なサイズの部 分構造に分割設計し, 部分構造ごとに精度良く展開特性を 評価しても，結合後に生じる展開同期誤差や結合誤差によ

\footnotetext{
*1 (C) 2005 日本航空宇宙学会

平成 17 年 3 月 9 日原稿受理

*2 NTT ドコモ

*3 東京工業大学

${ }^{* 4}$ 日本電信電話 (株) NTT 未来ねつと研究所
}

り展開特性は大きく変化する．また，展開同期誤差や結合 誤差が展開特性に与える影響について部分構造の地上展開 試験で評価することは困難である，乥こで, 著者らは部分 構造の結合が展開特性に与える影響を明らかにすることに より, 部分構造の地上展開試験結果から部分構造を結合し た状態の展開特性を予測する展開特性評価法を提案する． これまでの研究で, 展開同期誤差は展開力を減少させるが， 全ての部分構造の展開動作が制御されている場合, 展開同 期誤差は展開動作を妨げないこと, 構造破壊を引き起こさ ないことを明らかにしている9 $。$

本論文では，結合誤差と展開力の定量的な関係を導くこ とを目的とし，まず結合誤差が展開力を変化させる要因を 明らかにし，次に試作した部分構造に結合誤差を与えた条 件で実施した微小重力展開試験及び微小重力展開解析から， 各要因が展開力へ与える影響を定量的に評価する .

\section{2. 結合誤差の影響}

結合誤差とは，製造公差に起因する部分構造の設計ノミ ナル形状からのずれを示す . この結合誤差は, 部分構造単 体では展開力に変化を与えず, 部分構造を相互に結合した 状態で展開力に影響を与える要因である . 部分構造として 展開モジュール構造を 3 基作成し，展開モジュール構造を 最大 3 基結合した状態で展開試験を行った . 展開モジュール 構造を吊り下げた状態で実施する地上展開試験では, 重力 補償誤差による展開力の変化が生ずるために, 結合誤差の 影響を十分な精度で評価することができない, 弚こで, 微 小重力環境において, 結合誤差がない場合と結合誤差を有 する場合の展開試験を実施した，乥して，展開試験結果を 解析モデルを用いて評価することにより，結合誤差が展開 力に影響する要因, 結合誤差に対する展開力の变化量を明 らかにした . 展開解析は NTT で開発した柔軟多体構造物 


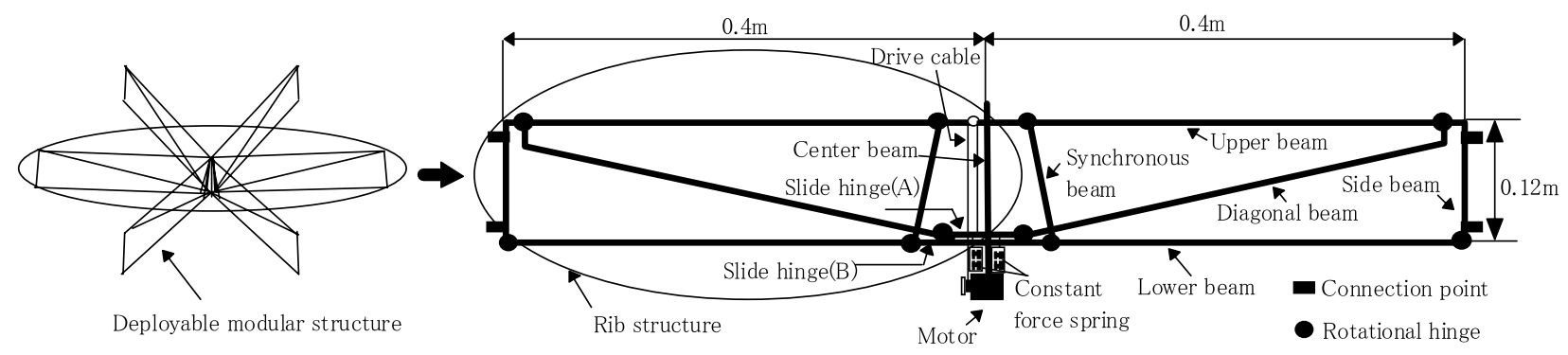

第 1 図＼cjkstart展開モジュール構造

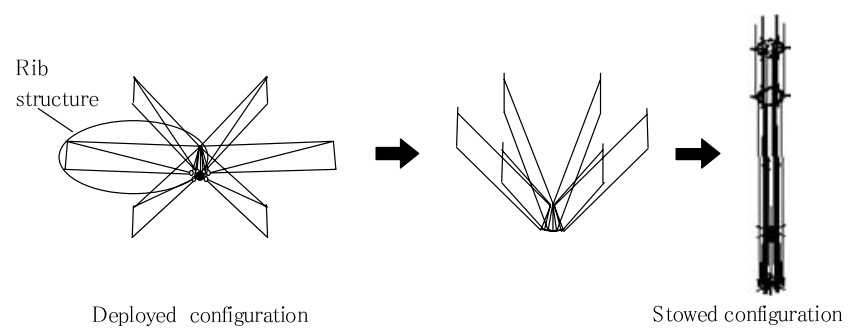

第 2 図＼cjkstart展開モジュール構造の展開収納状態

解析プログラム SPADE (Simple coordinate Partitioning Algorithm based Dynamics and finite Elements) ${ }^{10)}$ を用 いて行った。

2.1 展開モジュール構造 展開モジュール構造は, NTT において研究開発した大形展開反射鏡の支持構造 ${ }^{11)}$ をもと に作成した . 展開モジュール構造は第 1 图のように中心部材

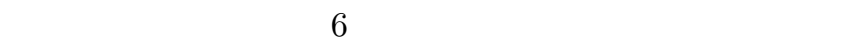
れのリブ構造は上部材 (Upper beam) , 斜部材 (Diagonal beam)，下部材 (Lower beam)，縦部材 (Side beam)，2 本の同期部材 (Synchronous beam) で構成した . 各部材 は回転ヒンジ (リブ構造に垂直な軸周りに自由度を有する) により結合している．斜部材間及び下部材間は光れ光れス ライドヒンジ (A)，(B) を介して結合しており，スライド ヒンジ (A) が中心部材 (Center beam) に沿って上下に 移動することで展開/収納する構造である．スライドヒン ジ (A) が下端から $0.1 \mathrm{~m}$ 上方へ移動すると完全に収納す る.回転ヒンジ , スライドヒンジ $(\mathrm{A})$ ，(B) と中心部材 との接触面は, PTFE (4 フッ化エチレン樹脂) ブッシュ による潤滑を施した . スライドヒンジ (A) にはスライド ヒンジ $(\mathrm{A})$ を下方向に引き下げる 2 つのコンストンばね (Constant force spring) と制御ヶーブル (Drive cable) を介して展開制御のためのモータ 1 個を取り付けており， モータが制御ケーブルを巻き取るとスライドヒンジ $(\mathrm{A})$ が 上昇して展開モジュール構造が収納し, 送り出すとスライ ドヒンジ (A) か下降して展開する . 展開モジュール構造の 展開から収納までの形態を第 2 図に示す . 制御ヶーブルに おける展開時と収納時の張力の平均プロファイルを展開力 として算出する . 展開モジュール構造の寸法は展開試験の ために使用する航空機キャビンの大きさを考慮して，展開 モジュール構造の展開状態の長さは $0.8 \mathrm{~m}$, 収納時の長さは $0.11 \mathrm{~m}$, 質量は $4.6 \mathrm{~kg}$ とした . 展開モジュール構造間は縦

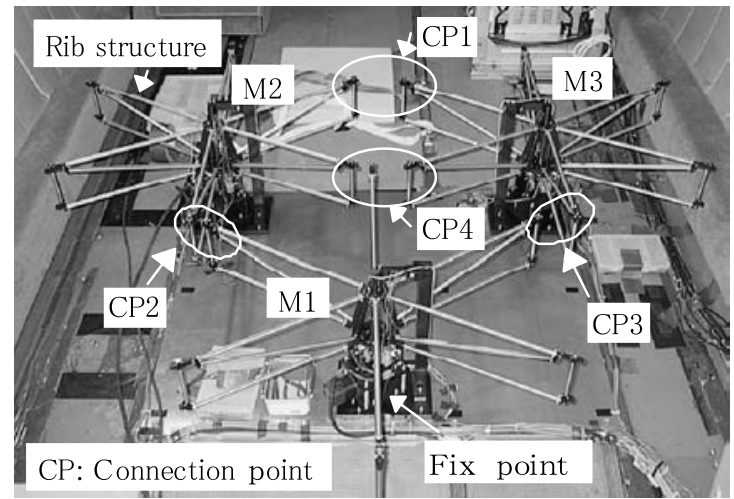

第3図微小重力展開試験の試験形態

部材の上下 2 力所に設置した結合部 (Connection point) で回転ヒンジ (縦部材と平行な軸周りに自由度を有する) により結合する．

2.2 微小重力展開試験 航空機の放物線飛行により得 られる微小重力環境において展開試験を実施した . 第 3 図 は航空機内の展開モジュール構造の設置状態及び結合部を 示しており，展開モジュール構造は中心部材のモ一タ側端 点を航空機キャビンの床面に固定した . 展開モジュール構 造を複数結合した状態では, 展開収納に伴い乥れ年れの展 開モジュール構造が床と平行に移動するため，1 つの展開 モジュール構造 M1 のみ飛行機の床面に固定し，他の展開 モジュール構造 M2，M3 は床に固定していない . 1 回の微 小重力環境の継続時間 ( 27 秒) を考慮して試験時間は 20 秒とした . 展開/収納動作中の制御ヶーブル張力 , 及びスラ イドヒンジ $(\mathrm{A})$ の下端からの変位量を測定することによ り，展開位置と展開力の関係を得た .

実施した展開試験の条件を以下に示す . 展開及び収納動 作の測定は再現性を確認するために同条件の展開試験を 3 回ずつ実施した .

(1) 展開モジュール構造単体の展開試験

解析モデルを作成するために，展開モジュール構造 (M1〜M3) 単体に対して，展開試験を実施した。

（2）展開モジュール構造を 2 基結合した状態の展開試験 展開モジュール構造 M1，M2 を結合した状態で, 結合誤 差がない場合と結合誤差を有する場合で展開試験を実施し た . 展開モジュール構造 1 基あたり複数のリブ構造に結合 誤差を有する場合の評価は，展開モジュール構造を 3 基結 
第 1 表 結合誤差 $(0.003 \mathrm{~m})$ による展開力の変化量

\begin{tabular}{lcc}
\hline & 2-Module assembly & 3-Module assembly \\
\hline $\begin{array}{l}\text { Difference of } \\
\text { deployment force }(\mathrm{N})\end{array}$ & 0.98 & 1.98 \\
\hline
\end{tabular}

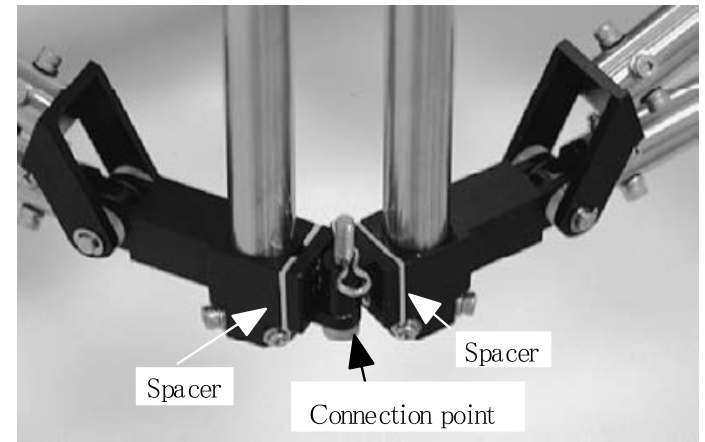

第 4 図 微小重力展開試験の結合誤差

合した状態で実施するため，展開モジュール構造を 2 基結 合した状態では，結合部 CP2 のみ結合誤差を設定した . 結 合誤差は展開モジュール構造の結合部 $\mathrm{CP} 2$ の上下 2 力所 に，結合誤差を想定した厚さ $0.003 \mathrm{~m}$ の板 (第 4 図) を取 り付けることにより付与した .

（3）展開モジュール構造を 3 基結合した状態の展開試験 展開モジュール構造 M1，M2，M3 を結合した状態で, 結 合誤差がない場合と結合誤差を有する場合で展開試験を実 施した . 結合誤差は展開モジュール構造の結合部 CP1〜3 の上下 2 力所に，結合誤差を想定した厚さ $0.003 \mathrm{~m}$ の板を 取り付けることにより付与した . 3 個のリブ構造が結合す る結合部 CP4 に結合誤差を与えた場合, 結合することが困 難であるため，本展開試験では結合部 CP4 に結合誤差を設 定していない .

展開モジュール構造を 2 基及び 3 基結合した状態で , 結 合誤差 $0.003 \mathrm{~m}$ を与えた場合の展開モジュール構造の展開 力の変化量を第 1 表に示す. 第 1 表における展開力の变化 量は, 結合誤差がない場合の展開モジュール構造 M1 の展開 力から結合誤差 $0.003 \mathrm{~m}$ を与えた場合の展開モジュール構 造 M1 の展開力を減じた值の最大值であり，第 1 表から結 合誤差により展開力が減少していることが明らかになった

また, 結合誤差に起因する展開モジュール構造の変形形 状は面外 (リブ構造を形成する平面に垂直な方向) 曲け変形 であると考えられるため, 展開試験においてリブ構造の下 部材中央の歪みを測定した . 第 5 図に軸方向および面外曲 げ方向の展開位置に対する歪み変化を示す . 展開モジュー ル構造が展開するに従い面外曲げ方向の歪みか増加してお り，展開モジュール構造が結合誤差を有する場合は面外曲 げ変形が支配的になる。

2.3 結合誤差が展開力に影響する要因 結合誤差が展 開力に影響する要因について，検討を行った . 結合誤差を 有する場合に展開モジュール構造に部材変形が生じ, 以下 の 2 つの影響があると仮定した .

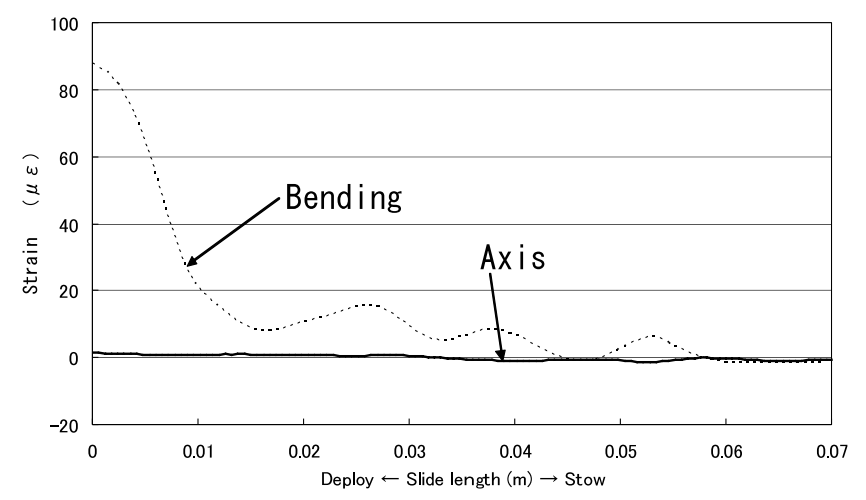

第 5 図 部材歪みの変化 (下部材)

(1) 歪みエネルギの影響

展開モジュール構造の部材変形により展開エネルギが歪 みエネルギとして散逸し，展開力が減少する．

(2) 摩擦力の影響

展開モジュール構造の部材変形によりヒンジ部が押しつ けられて摩擦力が増加し，展開力が減少する．

上記 2 つの要因が展開力に与える影響について展開モ ジュール構造の解析モデルを使用して評価を行った .

2.3.1 解析モデル 展開モジュール構造の解析モデルは 幾何形状, 質量特性, 材料特性及びコンストンばねによる展 開力を考慮してモデル化し, 材料特性は設計値, 質量特性は $1 \%$ 以下の誤差で測定した . また，微小重力展開試験より求 めた展開モジュール構造単体の展開力を真の展開力と仮定 して解析モデルに用いた . 本稿で着目している結合誤差は 形状誤差に起因するため，展開モジュール構造の幾何形状 を正確に解析モデルに反映する必要がある．乥こで，展開 モジュール構造の各回転ヒンジ及び結合部を測定点として 設定し，この点における展開から収納までの位置を $0.1 \%$ 以 下の誤差で測定した。

2.3.2 歪みエネルギの影響 まず, 2 基の展開モジュー ル構造を結合した状態を考える．展開モジュール構造を 2 基結合した状態において，結合部 CP2 のみ結合誤差を与え た条件で評価した . 展開解析において, 収納から展開まで の全歪みエネルギの変化量を算出し, 弚の全変化量が展開 エネルギから散逸したと仮定して展開力を導くと過大評価 になる ${ }^{12)}$.これは, 歪みエネルギの変化が結合誤差による 構造の歪みだけでなく，制御ケーブル等により影響を受け るためである．乥こで，結合誤差による部材歪みを明らか にするために，感度解析を行った . 2.2 節て結合誤差による 変形形状は, 面外曲け変形が支配的であることから，展開 モジュール構造のリブ構造単体の解析モデル (第 6 図) を 作成し，各回転ヒンジに面外荷重 $(0.98 \mathrm{~N})$ を加えたとき の展開力方向の抵抗力 $F$ を導いた . 感度解析の結果を第 2 


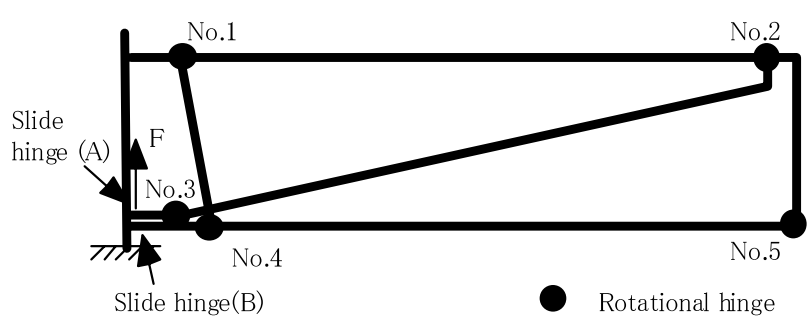

第6 図 リブ構造の感度解析モデル

\begin{tabular}{cc} 
第 2 表 & 面外荷重と抵抗力の関係 \\
\hline Hinge & Resistance force $(\mathrm{N})$ \\
\hline No. 1 & $3.9 \mathrm{E}-05$ \\
No. 2 & $5.1 \mathrm{E}-04$ \\
No. 3 & $3.9 \mathrm{E}-05$ \\
No. 4 & $3.9 \mathrm{E}-05$ \\
No. 5 & $2.7 \mathrm{E}-01$ \\
\hline
\end{tabular}

第 3 表 回転ヒンジの摩擦力と抵抗力の関係

\begin{tabular}{lc}
\hline Hinge & Resistance force $(\mathrm{N})$ \\
\hline No. 1 & $4.2 \mathrm{E}-04$ \\
No. 2 & $3.3 \mathrm{E}-03$ \\
No. 3 & $1.4 \mathrm{E}-04$ \\
No. 4 & $3.3 \mathrm{E}-03$ \\
No. 5 & $3.3 \mathrm{E}-03$ \\
\hline
\end{tabular}

表に示す. 第 2 表を参照すると，No. 5 の回転ヒンジに面 外荷重を作用させた場合の展開力方向に発生する抵抗力が 他の場合と比較して約 $10^{4}$ 倍と極端に大きい．これは，各 回転ヒンジに面外荷重を加えた際に生じる斜め材の軸力の 増加量に比例しており，この軸力により抵抗力 $F$ が発生し ているためである．乥こで，展開解析において，収納から 展開までのスライドヒンジ $(\mathrm{A})$ の変位量あたりの下部材 の歪みエネルギの変化量を算出し，下部材の歪みエネルギ の変化量をスライドヒンジ $(\mathrm{A})$ の変位量で除することに より，展開力の変化量を算出すると $1.05 \mathrm{~N}$ となる .

2.3.3 摩擦力の影響 ヒンジ部の摩擦力の影響に関して も前項と同樣に第 5 图の解析モデルを用いて, 回転ヒンジ に摩擦力を与えたときの展開力方向への抵抗力を評価した 部材先端のモーメントカと部材の軸力が回転ヒンジの摩擦 力を発生していると仮定し, 回転ヒンジに摩擦力 $(0.98 \mathrm{~N})$ を与えた場合の展開力方向への抵抗力 $F$ の感度解析結果を 第 3 表に示す. 第 3 表を参照すると，第 2 表と異なり回転 ヒンジに対する感度の差がほとんどない .よって，全ての 回転ヒンジに対して，ヒンジ荷重を設定した . 先端にモ一 メントカを受ける梁を仮定して , 展開解析で各部材の曲げ 歪みエネルギの収納から展開までの变化量を算出し, カス テリアノの定理 ${ }^{13)}$ を用いてモーメントカによるヒンジ荷重 を導いた .さらに, 部材か軸方向に押しつけられている荷 重は, 展開解析で各部材の伸び歪みエネルギの収納から展 開までの变化量を算出し, カステリアノの定理により導い た、モーメントによるヒンジ荷重と軸力によるヒンジ荷重 の合計に摩擦係数 0.05 (PTFE と金属の動摩擦係数) ${ }^{14}$ を

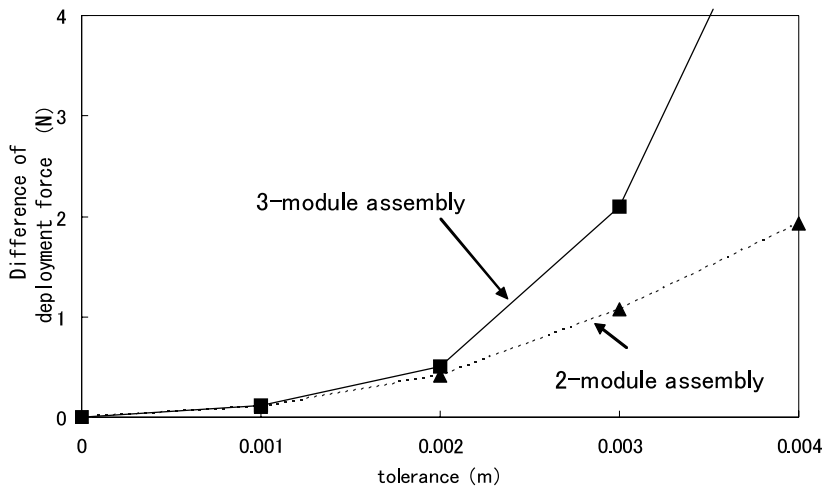

第7图 結合誤差に対する展開力の変化量

乗じた值を第 6 図の各回転ヒンジに摩擦力として設定し， 展開力の変化量を算出すると $0.02 \mathrm{~N}$ となる.

2.3.4 展開試験結果と展開解析結果の比較 展開モジュー ル構造を 2 基及び 3 基結合した状態で, 2.3.2 項及び 2.3 .3 項の手法を用いて導いた結合誤差 $0.003 \mathrm{~m}$ に対する展開力 の変化量を第 4 表に示す. 第 4 表において, 展開力の変化 量とは, 歪みエネルギの影響と摩擦力の影響の和を示す.第 4 表には展開試験結果も示す. 第 4 表の展開試験結果と展 開解析結果の比較から, 歪みエネルギの影響と摩擦力の影 響を考慮することにより，90\%以上の精度で結合誤差に対 する展開力の変化量を評価することが可能であることが明 らかになった .

次に, 展開モジュール構造を 2 基及び 3 基結合した状態 で, 展開力に対する歪みエネルギの影響と摩擦力の影響を 弚れ光れ第 5 表に示す. 第 5 表を参照すると，摩擦力の影 響は歪みエネルギの影響の $2 \%$ 以下となり，結合誤差の展 開力に影響する主要因は歪みエネルギの影響である .

2.4 結合誤差に対する展開力の変化量 展開モジュー ル構造を 2 基及び 3 基結合した状態で, 誤差量を $0.001 〜$ $0.004 \mathrm{~m}$ まで変化させ , 2.3.1 項及び 2.3.2 項の手法を用い て導いた展開力の変化量を第 7 図に示す .ここで, 展開力 の変化量とは, 歪みエネルギの影響と摩擦力の影響の和を 示す. 第 7 图のように結合誤差に対する展開力の変化量を 明らかにすることにより，例えば展開モジュール構造の製 造公差が $0.001 \mathrm{~m}$ と仮定すると，第 7 図から展開モジュー ル構造を 3 基結合した場合の展開力の変化量は $0.1 \mathrm{~N}$ であ るということが導かれ，展開モジュール構造のばね力を決 定する際の重要な指針となる .

次に, 展開モジュール構造を複数結合した状態 (第 8 図) を想定すると，展開モジュール構造 1 基あたりリブ構造が 2 個結合する部分は 2 力所が最大となる.よって，第 8 図 の展開モジュール構造を 3 基結合した状態の結合誤差に対 する展開力の変化量が, 複数の展開モジュール構造を結合 した場合の結合誤差に対する展開力の変化量にも使用可能 であると考えられる .

さらに，今回使用した展開モジュール構造以外にも結合 して面を形成する構造として, 3 本, 4 本のリブ構造をもつ 
第 4 表 展開解析結果と展開試験結果の比較

\begin{tabular}{lccccc}
\hline & \multicolumn{2}{c}{ 2-Module assembly } & & \multicolumn{2}{c}{ 3-Module assembly } \\
\cline { 2 - 3 } \cline { 5 - 6 } & Experiment & Analysis & & Experiment & Analysis \\
\hline $\begin{array}{l}\text { Difference of } \\
\text { deployment force }(\mathrm{N})\end{array}$ & 0.98 & 1.07 & & 1.98 & 2.10 \\
\hline
\end{tabular}

第 5 表 歪みエネルギの影響と摩擦力の影響の比較

\begin{tabular}{lccccc}
\hline & \multicolumn{2}{c}{ 2-Module assembly } & & \multicolumn{2}{c}{3 -Module assembly } \\
\cline { 2 - 3 } $\begin{array}{l}\text { Difference of } \\
\text { deployment force }(\mathrm{N})\end{array}$ & 1.05 & 0.02 & & 2.06 & 0.04 \\
\hline
\end{tabular}

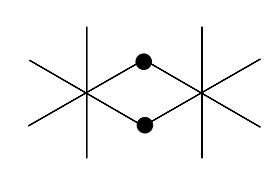

2-module assembly

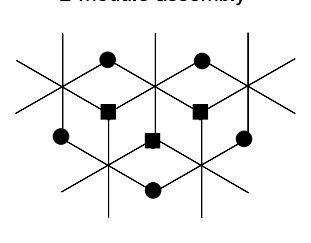

5-module assembly

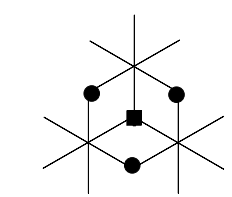

3-module assembly

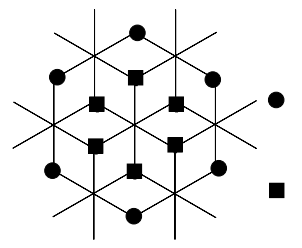

7-module assembly
Connection point (by 2 Rib structures)

Connection point (by 3 Rib structures)

第 8 図 展開モジュール構造の結合状態

部分構造が考えられる.これらの構造に関してもリブ構造 6 本のときと同樣に, リブ構造に対して面外曲げ変形が生 じる. また，部分構造あたりの面外変形を生じるリブ構造 の数も 2 本と同一であることから, リブ構造 6 本の展開モ ジュール構造と同一の評価が可能である .

\section{3. 結論}

本論文は, 部分構造を結合した場合に展開力を変化させ る要因として結合誤差に着目し, 結合誤差を与えることが 可能な部分構造である展開モジュール構造を用いて単体及 び複数を結合した状態で微小重力展開試験及び微小重力展 開解析を行うことにより，以下の結論を得た 。

1) 結合誤差が展開力に与える影響を, 部材変形により展 開エネルギが歪みエネルギとして散逸し展開力を減少させ ること, ヒンジ部の摩擦力が増大し展開力を減少させるこ との 2 つの仮定て説明し，検証した .

2) 結合誤差が展開力に影響する主要因は, 部材変形によ り展開エネルギが歪みエネルギとして散逸し展開力を減少 させることである .

3) 結合誤差に対する展開力の変化量を定量的に明らかに した .

\section{参 考 文 献}

1) Thomson, M. W.: Astromesh Deployable Reflectors for KuBand Commercial Satellites, ICSSC, AIAA 2002-2032, 2002.

2) Meguro, A., Harada, S. and Watanabe, M.: An Ultra-Light Large Antenna Reflector for Communication Satellites, 54th International Astronautical Congress, IAF-03-I.1.06, 2003.

3) Honma, M., Yoshimoto, S., Natori, N. and Tsutsumi, Y.: Engineering Test Satellite- 8 for Mobile Communications and Navigation Experiment, 51st International Astronautical Congress IAF-00-M.3.01, 2000.

4) Ishikawa, H. and Meguro, A.: Relationship between the Difficulty Index Value and Evaluation Accuracy of Ground Deployment Testing, Proceedings of 36th Aerospace Mechanisms Symposium, 2002, pp. 353-363.

5) 石川博規, 目黑 在 : 大形展開宇宙構造物の展開力評価精度に関 する研究, 日本航空宇宙学会論文集, 51 (2003), pp. 164-168.

6) 目黑 在, 三次 仁, 安藤和秀: モジュール化ケーブルメッシュ 展開構造による大形衛星通信アンテナの実現，電気情報通信学会 論文誌 B-II, J76-B-II (1993), pp. 476-484.

7) Mitsugi, J. and Yasaka, T.: Deployable Modular Mesh Antenna Concept and Feasibility, Proceedings of 17th International Symposium on Space Technology and Science, Vol. 1, 1990, pp. 599-604.

8) Miyasaka, A., Honma, M., Tsujihata, A., Nakamura, K., Yamada, K. and Meguro, A.: Design and Ground Verification of Large Deployable Antenna, Proceedings of 42nd Structures Structural Dynamics and Material Conference, AIAA 01-1480, 2001.

9) Ishikawa, H., Meguro, A. and Watanabe, M.: Effect of Synchronization Errors on Deployment Characteristics of Modularized Structures, Trans. Jpn. Soc. Aeronaut. Space Sci., 47 (2004), pp. $175-180$.

10) Mitsugi, J.: Direct Coordinate Partitioning for Multibody Dynamics Based on Finite Element Method, Proceedings of 36th Structures Structural Dynamics and Material Conference, AIAA 95-1442-CP, 1995, pp. 2481-2487.

11) Meguro, A., Harada, S. and Watanabe, M.: Key Technologies for High Accuracy Large Mesh Antenna Reflectors, 51st International Astronautical Congress, IAF-00-I.1.05, 2000.

12）石川博規, 目黑 在, 渡辺光庸 : モジュール構造の結合が展開特 性に与える影響，第 45 回構造強度に関する講演会講演集，2003， pp. 197-199.

13) 平 修二: 現代 材料力学, オーム社, 東京, 1992, p. 126.

14) 日本機械学会: 機械工学便覧, A3 編, 丸善, 東京, 1987, pp. $32-35$. 